\title{
HUBUNGAN TINGKAT PENGETAHUAN IBU DENGAN KEBERHASILAN ASI EKSKLUSIF DI WILAYAH KERJA PUSKESMAS PEJERUK
}

\author{
Lani Ingga Budiarsih ${ }^{1}$, Rahmani Ramli $^{2}$, Febriati Astuti ${ }^{3}$ \\ ${ }^{1}$ Mahasiswa Sekolah Tinggi Ilmu Kesehatan (STIKES) Mataram \\ ${ }^{2,3)}$ Staf Pengajar Sekolah Tinggi Ilmu Kesehatan (STIKES) Mataram \\ laniingga@yahoo.com
}

\begin{abstract}
ABSTRAK
Asi eksklusif memiliki kontribusi yang besar terhadap tumbuh kembang anak dan daya tahan tubuh anak. Salah satu faktor yang mempengaruhi pemberian ASI eksklusif adalah pengetahuan ibu.

Penelitian ini bertujuan untuk mengidentifikasi hubungan tingkat pengetahuan dengan pemberian ASI eksklusif di wilayah kerja Puskesmas Pejeruk. Design penelitian ini adalah deskripsi analitik korelasi dengan pendekatan "Cross Sectional". Teknik pengambilan sampel pada penelitian ini menggunakan purposive sampling dengan jumlah 100 responden. Pengumpulan data dilakukan pada tanggal 26 Februari 2019-4 Maret 2019, dengan menggunakan kuesioner. Analisa data menggunakan uji spearman rank dengan $\alpha=0,05$.

Hasil Uji statistik spearman rank menunjukkan bahwa ada hubungan tingkat pengetahuan dengan pemberian ASi eksklusif di wilayah kerja Puskesmas Pejeruk dengan nilai $\mathrm{p}=0,001(\mathrm{p}<\alpha)$.

Berdasarkan penelitian yang telah dilakukan diharapkan dapat memberikan informasi bagi masyarakat dan fasilitas kesehatan setempat untuk lebih meningkatkan penyuluhan tentang ASI Eksklusif di Wilayah kerja Puskesmas Pejeruk.
\end{abstract}

Kata kunci: Tingkat Pengetahuan, Ibu Menyusui, ASI Eksklusif.

\section{PENDAHULUAN}

Menyusui adalah hak ibu, dan menyusu adalah hak bayi yang perlu mendapat dukungan (Fitra Sukrita Irsal dr, 2017).

Menurut WHO/UNICEF, standar emas pemberian makan pada bayi dan anak adalah segera menyusui dalam 1 jam setelah lahir, menyusui bayi secara eksklusif sejak lahir sampai dengan umur 6 bulan. Asi eksklusif memiliki kontribusi yang besar terhadap tumbuh kembang anak dan daya tahan tubuh anak.

Menurut dari data WHO, sebesar $53 \%$ penyebab kematian bayi berasal dari kurangnya nutrisi pada bayi dimasa vital yakni saat perkembangan otak diperiode emas kehidupannya tersebut (Dwi Luthfi, 2018).

Data Badan Kesehatan Dunia (WHO) tahun 2016 masih menunjukkan rata-rata angka pemberian ASI Eksklusif di dunia baru berkisar 38\% (Pramitha Ecka, 2017). Angka pemberian ASI Eksklusif di Indonesia masih tergolong rendah. Menurut pusat data dan informasi Kementrian dan Kesehatan 2017, pemberian ASI Eksklusif di Indonesia hanya $35 \%$. Angka tersebut masih jauh di bawah rekomendasi WHO (Badan Kesehatan Dunia) yang sebesar 50\% (Astuti Indriyani, 2018).

Keberhasilan pemberian ASI Eksklusif dipengaruhi oleh beberapa 
faktor,salah satunya adalah pengetahuan ibu tentang ASI Eksklusif (Rohani, 2007). Hal ini ditunjukkan akan terjadi peningkatan pemberian ASI Eksklusif jika disertai dengan peningkatan pengetahuan tentang ASI Eksklusif (Sugiarti, 2011).

Berdasarkan hasil penelitian yang dilakukan oleh Mariane Wowor, Joice M. Laoh dan Damajanty H.C Pangemanan bahwa ada hubungan pengetahuan dan sikap ibu dengan pemberian ASI Eksklusif. Maka dapat disimpulkan bahwa semakin tinggi tingkat pengetahuan ibu, maka semakin tinggi pula kesadarannya untuk memberikan ASI Eksklusif kepada bayinya (Susmaneli Herlina,2012).

Cakupan ASI Eksklusif di NTB tahun 2016 sebesar 86,63\% meningkat jika dibandingkan tahun 2015 yang hanya mencapai $76,88 \%$ (Eka Nurhandini dr,2017). Cakupan ASI Eksklusif di kota Mataram tahun 2015 untuk Puskesmas Pejeruk menduduki peringkat 10 dari 11 peringkat yaitu sebesar 51,88\% (Profil Kesehatan kota Mataram,2015).

Berdasarkan data awal melalui survey pendahuluan yang dilakukan di Puskesmas Pejeruk untuk cakupan pemberian ASI Eksklusif pada tahun 2016 adalah 66,93\%, dan pada tahun 2017 adalah $51,17 \%$ dimana mengalami penurunan sebesar $15,76 \%$ dan belum mencapai target pemerintah yaitu $80 \%$. Berdasarkan data dari puskesmas pejeruk pada 3 bulan terakhir ini yaitu bulan Juni 2018 didapatkan dari $197 \mathrm{ibu}$,yang memberikan ASI Eksklusif sebanyak 86 orang $(30,6 \%)$, tidak ASI Eksklusif sebanyak 111 orang $(69,4 \%)$. Pada bulan Juli 2018 didapatkan dari 195 ibu, yang memberikan ASI Eksklusif sebanyak 94 orang $(27,1 \%)$, tidak ASI Eksklusif sebanyak 101 orang (72,9\%). Dan pada bulan Agustus 2018 didapatkan dari 163 ibu, yang memberikan ASI Eksklusif sebanyak 86 orang $(38,1 \%)$, tidak ASI Eksklusif sebanyak 77 orang $(61,9 \%)$. Dari data tersebut diketahui bahwa kegagalan dalam pemberian ASI Eksklusif dikarenakan ibu telah memberikan bayinya makanan tambahan seperti madu dan bubur pada usia 4-6 bulan, yang seharusnya bayi hanya diberikan ASI Eksklusif saja, ini dikarenakan bayi rewel sehingga bayi tidak mau menyusu.

Penelitian ini bertujuan untuk mengetahui hubungan tingkat pengetahuan ibu dengan keberhasilan ASI Eksklusif di wilayah kerja Puskesmas Pejeruk.

\section{METODE}

Deskripsi analitik korelasi dengan pendekatan "Cross Sectional". Penelitian ini dilaksanakan pada bulan Februari-Maret 2019. Responden penelitian ini berjumlah 100 orang di Wilayah Kerja Puskesmas Pajeruk. Data tingkat pengetahuan diperoleh menggunakan kuesioner, sedangkan data keberhasilan ASI Eksklusif diperoleh dengan menggunakan kuesioner ASI Eksklusif. Uji statistik menggunakan Uji korelasi spearman rank dengan SPSS 16.

\section{HASIL}

\section{A. Karakteristik Responden}

Tabel 1. Distribusi Karakteristik Responden

\begin{tabular}{clcc}
\hline No & \multicolumn{1}{c}{ Variabel } & $(\mathbf{N})$ & $(\mathbf{\%})$ \\
\hline 1. & Umur (Tahun): & & \\
& $-<21$ tahun & 5 & 5.0 \\
& $-21-35$ tahun & 81 & 81.0 \\
& $->35$ tahun & 14 & 14.0 \\
\hline 2. & Pendidikan : & & \\
& - Tidak sekolah & 1 & 1.0 \\
& - SD & 5 & 5.0 \\
& - SMP & 24 & 24.0 \\
& - SMA & 63 & 63.0 \\
& - S1 & 7 & 7.0 \\
\hline 3. & Pekerjaan: & & \\
\hline
\end{tabular}




\begin{tabular}{lcc}
\hline Guru & 4 & 4.0 \\
IRT & 80 & 80.0 \\
Pedagang & 3 & 3.0 \\
Swasta & 11 & 11.0 \\
Tani & 2 & 2.0 \\
\hline Berdasarkan & tabel & 4.2
\end{tabular}

menunjukkan bahwa usia responden terbanyak yaitu 21-35 tahun 81 $(81 \%)$, sedangkan untuk tingkat pendidikan yang terbanyak yaitu tingkat pendidikan SMA sebanyak $63(63 \%)$ responden. Dan pekerjaan responden terbanyak yaitu IRT 80 responden.

\section{B. Tingkat Pengetahuan Ibu}

Tabel 2. Distribusi Tingkat Pengetahuan Ibu

\begin{tabular}{clcc}
\hline No & Pengetauan & $(\mathbf{N})$ & $(\%)$ \\
\hline 1 & Baik & 3 & 3.0 \\
2 & Cukup & 18 & 18.0 \\
3 & Kurang & 79 & 79.0 \\
\hline \multicolumn{2}{c}{ Total } & $\mathbf{1 0 0}$ & $\mathbf{1 0 0 . 0}$ \\
\hline
\end{tabular}

Berdasarkan tabel 4.3 menunjukan bahwa sebagian besar responden memiliki pengetahuan yang kurang yaitu sebanyak 79 orang $(79,0 \%)$ Kemudian responden yang memiliki pengetahuan cukup 18 orang (18.0\%),dan responden yang memiliki pengetahuan baik sebanyak 3 orang $(3.0 \%)$.

\section{Pemberian ASI Eksklusif}

Tabel 3. Distribusi Pemberian ASI Eksklusif

\begin{tabular}{clcc}
\hline \multirow{2}{*}{ No } & Pemberi ASI/Tidak & (n) & $(\boldsymbol{\%})$ \\
\hline 1 & Tidak ASI Eksklusif & 72 & 72.0 \\
2 & ASI Eksklusif & 28 & 28.0 \\
\hline & Total & $\mathbf{1 0 0}$ & $\mathbf{1 0 0 . 0}$ \\
\hline
\end{tabular}

Berdasarkan table $4.4 \mathrm{di}$ atas menunjukan lebih besar responden diwilayah kerja puskesmas berdasarkan pemberian ASI yaitu 72 orang $(72,0 \%)$ yang tidak memberikan ASI Eksklutif dibandingkan responden yang memberikan ASI eksklutif sebanyak 28 orang $(28 \%)$.

\section{Hubungan Tingkat Pengetahuan Ibu Dengan Pemberian Asi Eksklusif}

Berdasarkan hasil uji statistik Spearman rank test dengan bantuan SPSS v.16 diinterpretasikan sebagai berikut: nilai dari Spearman's rho diperoleh nilai $\mathrm{p}$-value adalah 0,000 . Dimana $(\alpha)<0,05$ sehingga dapat diambil kesimpulan Ho ditolak dan Ha diterima, berarti terdapat hubungan tingkat pengetahuan ibu dengan pemberian ASI Eksklusif di Wilayah kerja Puskesmas Pejeruk.

Berdasarkan

kekuatan

hubungan nilai koefisien korelasi 0,416 masuk dalam kategori cukup.Adapun hasil uji korelasi spearman tersebut dapat dilihat pada tabel 4. berikut:

Tabel 4. Hasil uji korelasi rank sperman Tingkat Pengetahuan Ibu Dengan Pemberian Asi Eksklusif

\begin{tabular}{cclcc}
\hline & & & $\begin{array}{c}\text { Tingkat } \\
\text { Pengeta } \\
\text { huan }\end{array}$ & $\begin{array}{c}\text { Kebe } \\
\text { rhasil } \\
\text { an } \\
\text { ASI }\end{array}$ \\
\hline $\begin{array}{c}\text { Spea } \\
\text { rma } \\
\text { n's } \\
\text { rho }\end{array}$ & $\begin{array}{c}\text { Tingkat } \\
\text { Pengetahuan }\end{array}$ & $\begin{array}{l}\text { Correlation } \\
\text { Coefficient }\end{array}$ & 1.000 & $.416^{* *}$ \\
& & Sig. (2-tailed) & & .000 \\
& Keberhasilan & Correlation & $.416^{* *}$ & 1.000 \\
& ASI & Coefficient & & \\
& & Sig. (2-tailed) & .000 & \\
& & N & 100 & 100 \\
\hline$* *$. Correlation is significant at the 0.01 level (2-tailed). &
\end{tabular}

\section{PEMBAHASAN}

Sebagian besar responden pada penelitian ini berusia 21-35 tahun sebanyak 81 orang $(81 \%)$. Hal ini sesuai dengan pernyataan Cunningham (2005) yang menyatakan bahwa usia dalam reproduksi memegang peranan penting. 
Umur 20-35 tahun merupakan umur produktif dimana organ reproduksi sudah siap karena hormon progesteron dan estrogen sudah stabil .

Namun, dilihat dari tingkat pendidikan responden terbanyak tingkat pendidikan SMA sebanyak 63 orang (63\%). Pendidikan merupakan penuntun manusia untuk berbuat dan mengisi kehidupan yang dapat digunakan untuk mendapatkan informasi sehingga dapat meningkatkan kualitas hidup. Semakin tinggi tingkat pendidikan semakin mudah seseorang untuk menerima informasi (Budiman dan Riyanto, 2018).

Berdasarkan tabel 2. di atas diketahui bahwa sebagian besar responden memiliki pengetahuan yang kurang yaitu sebanyak 79 orang $(79,0 \%)$.

Menurut Notoatmodjo (2014), pengetahuan merupakan hasil dari tahu, dan terjadi setelah seseorang melakukan penginderaan terhadap suatu objek tertentu. Penginderaan terjadi melalui panca indra manusia, yakni indra penglihatan, pendengar, penciuman, rasa dan raba. Sebagian besar pengetahuan manusia diperoleh melalui mata dan telinga yaitu proses melihat dan mendengar. Pengetahuan ibu yang cukup tentang ASI Eksklusif disebabkan masih sedikitnya informasi yang diperoleh ibu tentang ASI Eksklusif. Selama ini ibu hanya memperoleh informasi tentang ASI Eksklusif dari teman, keluarga dan media massa.

Berdasarkan tabel 3. diatas diketahui bahwa sebagian besar responden diatas tidak memberikan ASI Eksklusif yaitu 72 orang $(72,0 \%)$. Hal ini sesuai dengan penelitian yg dilakukan oleh Novita (2008) ibu yang mempunyai kesibukan di luar rumah, cenderung akan meninggalkan bayinya di rumah, sehingga tidak memiliki banyak kesempatan untuk menyusui bayinya. Banyak juga responden yang memberikan madu dan air putih dan buru-buru memberikan makanan tambahan, karena dinilai dengan memberikan madu,bayi akan tumbuh kuat dan sehat, dan ini cenderung ke budaya,karena budaya memiliki peran yang sangat besar dalam pemberian ASI Eksklusif, dimana budaya yang dianut seseorang secara turun temurun cenderung sulit untuk diperbaiki.

Banyak responden mengatakan produksi ASI kurang sehingga sebagian besar responden memutuskan untuk memberikan susu formula, karena dinilai susu formula bisa memenuhi kebutuhan gizi untuk bayinya, selain itu responden juga mengatakan memberikan madu untuk bayinya sejak lahir karena dinilai madu dapat memberikan kekebalan tubuh yang baik. Kemudian responden yang bekerja mengatakan tidak punya waktu untu memerah ASI sehingga memutuskan juga untuk memberikan bayinya susu formula.

Pengetahuan ibu tentang ASI Eksklusif adalah pengetahuan ibu tentang ASI dalam jumlah cukup merupakan makanan terbaik dan dapat memenuhi kebutuhan gizi bayi selama enam bulan pertama. Menurut Djami, dkk (2013) faktor-faktor yang dapat mempengaruhi pemberian ASI Eksklusif antara lain karakteristik ibu (pengetahuan, pendidikan, pekerjaan, usia, paritas dan etnis), karakteristik bayi (berat lahir dan kondisi kesehatan bayi), lingkungan (keyakinan, dukungan keluarga, tempat tinggal dan sosial ekonomi) dan pelayanan kesehatan (pemeriksaan kehamilan, konseling laktasi, tempat persalinan, penolong persalinan dan kebijakan). Semua faktor tersebut memiliki kontribusi tersendiri dalam terciptanya perilaku yang diharapkan dalam pemberian ASI Eksklusif. 


\section{SIMPULAN}

1. Didapatkan sebagian besar responden dengan tingkat pengetahuan yang kurang sebanyak 79 orang $(79,0 \%)$.

2. Didapatkan sebagian besar responden tidak melakukan pemberian ASI Eksklusif sebanyak 72 orang $(72,0 \%)$.

3. Terdapat hubungan yang signifikan antara tingkat pengetahuan ibu dengan keberhasilan ASI Eksklusif di wilayah kerja Puskesmas Pejeruk dengan nilai $\mathrm{p}$ value $=0,000<0,05$.

\section{DAFTAR PUSTAKA}

Dwi Luthfi,2018. Keajaiban ASI Eksklusif turunkan resiko kematian bayi. https://www.viva.co.id diakses tanggal 3 Oktober 2018.

Fitra Sukrita Irsal, (2017). A to z asi dan menyusui. Jakarta: pustaka bunda

Pramitha Ecka,2017. Pekan ASI Sedunia 2017, Mari dukung keberhasilan $i b u$ menyusui. https://majalahkartini.co.id. Diakses tanggal 4 Oktober 2018.

Kemenkes RI,(2017). PEDOMAN PENYELENGGARAAN PEKAN ASI SEDUNIA (PAS) TAHUN 2017. https://books.google.co.id. diakses tanggal 3 Oktober 2018

Eka Nurhandini dr, 2017. Profil Kesehatan Provinsi NTB 2016. http://depkes.go.id. Diakses tanggal 3 Agustus 2018

Astuti indriyani,2018. Pemberian ASI Eksklusif di Indonesia Hanya 35\%. http://m.mediaindonesia.com. Diakses tanggal 3 Oktober 2018.

Sugiarti (2011). Faktor Faktor yang Berhubungan dengan Pemberian ASI Eksklusif di kecamatan karang malang kabupaten sragen.(Skripsi Ilmiah). Surakarta: Fakultas Ilmu Kesehatan UMS .
Susmaneli Herlina, 2012. Faktor-faktor yang berhubungan dengan pemberian ASI Eksklusif dinwilayah kerja Puskesmas Rambah Hilir Ikabupaten Rokan Hulu Tahun 2012. https://scholar.google.co.id pada tanggal 8 Oktober 2018.

Dinas Kesehatan Kota Mataram 2018. Laporan Pemantauan wilayah Setempat Kesehatan Ibu dan Anak Kota Mataram 2015. Mataram: Dikes Kota Mataram.

Notoatmodjo.(2014).Pengertian Dan Tingkatan Pengetahuan. https://www.Trendilmu.com/2015. diakses tanggal 1 juni 2018. 